\title{
Morphological Basis for Yield Differences among Cowpea Varieties in the Sudan Savanna Zone of Nigeria
}

\author{
N. Kamai*, N.A. Gworgwor, I.A Sodangi \\ ${ }^{1}$ Department of Crop Production, University of Maiduguri
}

\begin{abstract}
Field trials were conducted at two locations, namely the Teaching and Research Farm, Faculty of Agriculture, University of Maiduguri, Maiduguri $\left(11^{\circ} 47.840^{\prime} \mathrm{N}\right.$; $13^{\circ} 12.021^{\prime} \mathrm{E}$; elevation $319 \mathrm{~m}$ asl) and Damboa $\left(11^{\circ} 10.736^{\prime} \mathrm{N} ; 12^{\circ} 47.100^{\prime} \mathrm{E}\right.$; elevation $398 \mathrm{~m}$ asl) on the trial site of the International Institute of Tropical Agriculture (IITA) in Borno State both in Sudan Savanna zone of Nigeria during the 2010 and 2011 rainy seasons. The objectives of the study were to evaluate the agronomic performances of some improved cowpea varieties and to identify the morphological traits associated with high grain yield in the Sudan Savanna zone of Nigeria. The trial consisted of eight treatments (cowpea varieties), which included two local varieties viz: Kannanado White and Borno Brown obtained from farmers in Damboa, Borno State and six improved varieties viz: IT90K-277-2, IT97K-568-18, IT89KD-288, IT97K-499-35, IT98K-131-2 and IT89KD-391 obtained from IITA stations in Kano and Maiduguri, Nigeria. The treatments/varieties were laid out in a randomized complete block design (RCBD) replicated three times at each site. The gross plot size was $5.0 \mathrm{mx}$ $4.0 \mathrm{~m}\left(20 \mathrm{~m}^{2}\right)$ while net plot size was $3.6 \mathrm{~m} \times 3.0 \mathrm{~m}\left(10.8 \mathrm{~m}^{2}\right)$. The results showed that the improved varieties produced significantly higher number of branches, peduncles, and pods per plant and number of seeds per pod than the local varieties. However, the local varieties produced significantly longer branches and higher number of branches though similar to that of the improved IT89KD-288 variety. Averaged over both locations in both years (overall mean) the results showed that cowpea grain yield was positively correlated with number of pods per plant, peduncle length and number of peduncles per plant. Conversely, the results indicated that cowpea grain yield was significantly negatively correlated with branch length. From the study the improved varieties performed better than the local varieties in the Sudan Savanna zone of Borno State. Among the improved varieties, IT90K-277-2, IT97K-499-35 and IT98K-131-2 were outstanding in terms of grain yield per hectare.
\end{abstract}

\section{Introduction}

Cowpea, Vigna unguiculata (L.) Walp, is a grain crop cultivated in a range of ecologies especially in the Savanna regions and in the tropics and subtropics (Singh et al., 1990; Anon., 2008). Cowpea, also popularly called 'beans' is mostly grown in dry areas in mixtures. It is thought that the origin of the cultivated species of cowpea is Africa (Gibbon and Pain, 1988). Cowpea is a legume of significant economic importance worldwide. Of the world's total production area of about 14 million hectares area under cowpea, West Africa alone accounts for about 9 million hectares or 64\% and 3 million tons of production (FAO, 2000; Singh, 2007). West Africa is the key cowpea producing zone, mainly in the dry Savanna and semi-arid agro-ecological zones. Nigeria is the largest cowpea producer in the world and also has the highest level of consumption (FAO, 2000; Singh, 2007). In Nigeria cowpea is largely grown in the northern part of the country which has Savanna type of vegetation and light rainfall (Anon., 2008). Cowpea is the most important source of nutritious food and fodder in West Africa (Singh, 2007) with 23-35\% protein in its grains. Therefore, cowpea has been referred to as "poor man's meat" (Nielsen et al., 1997). It is estimated that cowpea supplies $40 \%$ of the daily protein requirements to most people in Nigeria (Muleba et al., 1997). The use of cowpea haulms as fodder is attractive in mixed crop/livestock systems where both grain and fodder can be obtained from the same crop (Tarawali et al., 1997). Due to several constraints the average cowpea grain production in West Africa was reported to be as low as $358 \mathrm{~kg} / \mathrm{ha}$ (FAO, 2000) whereas Singh et al. (1997) estimated $240 \mathrm{~kg} / \mathrm{ha}$ cowpea grain yield as an average for northern Nigeria. In most parts of Borno State, rainfall is unreliable and frequently less and poorly distributed for a good cowpea crop. In the Sudan savanna, early season and terminal drought conditions are almost an annual event (Onyibe et al., 2006). Improving the yield of cowpea in the State requires the use of drought-tolerant and drought-avoidance varieties.

The local cowpea varieties are late maturing, low yielding and photosensitive and very susceptible to drought and heat. Even in the average year, the cowpea cultivars have to rely on moisture stored in the soil after the rains have stopped for grain filling. The crop performs poorly if the rains end early (Raheja, 1986). The improved varieties have acceptable seed quality for various regions, and are resistant to major diseases and the parasitic weed Striga gesnerioides. They also have synchronous flowering and maturity (Singh, 1994). The improved varieties are therefore early maturing, photoinsensitive and have high yield potential even with less rainfall. In the same vein the improved cowpea varieties have varying degree of yield potentials which could be 
due to differences in their morphological traits in the dry ecologies of Borno State. Therefore, the need to try these promising cowpea varieties for their adaptability in the sudan savanna zone of Nigeria is obvious as one of the strategies for improving the productivity of the crop in this region since no information is available on the performance of these varieties in this zone. Information on morphological differences of the different cowpea varieties will be valuable for future strategies in the development of high yielding cowpeas for the sudan savanna zone of Nigeria. The objectives of the study were to evaluate the agronomic performances and to identify morphological traits associated with high grain yield of some improved cowpea varieties in Sudan Savanna zone of Nigeria.

\section{Materials and Methods}

The study was conducted at the Teaching and Research Farm, Faculty of Agriculture, University of Maiduguri, Maiduguri $\left(11^{\circ} 47.840^{\prime} \mathrm{N} ; 3^{\circ} 12.021^{\prime} \mathrm{E}\right.$; elevation $319 \mathrm{~m}$ asl $)$ and at Damboa $\left(11^{\circ} 10.736^{\prime} \mathrm{N} ; 12\right.$ ${ }^{\circ} 47.100^{\prime} \mathrm{E}$; elevation $398 \mathrm{~m}$ asl) on the trial site of the International Institute of Tropical Agriculture (IITA) in Borno State both in Sudan savanna zone of Nigeria during the 2010 and 2011 rainy seasons, August to November each year. The gross plot size was $5.0 \mathrm{~m} \mathrm{x} 4.0 \mathrm{~m}\left(20 \mathrm{~m}^{2}\right)$ and the net plot size was $3.6 \mathrm{~m} \times 3.0 \mathrm{~m}(10.8$ $\mathrm{m}^{2}$ ). Each plot contained eight (8) rows of $4.0 \mathrm{~m}$ long with spacing of $0.75 \mathrm{~m}$ between rows and $0.2 \mathrm{~m}$ between plants. The trial consisted of 8 treatments (varieties of cowpea). The treatments included two local varieties viz: Kannanado White and Borno Brown and 6 improved varieties viz: IT90K-277-2, IT97K-568-18, IT89KD-288, IT97K-499-35, IT98K-131-2 and IT89KD-391. The treatments/varieties were laid out in a randomized complete block design (RCBD) replicated 3 times at each site. Morphological parameters measured number of branches per plant, branch length $(\mathrm{cm})$, number of peduncles per plant, peduncle length $(\mathrm{cm})$, number of pods per plant, number of seeds per pod, pod length $(\mathrm{cm})$, number of matured seeds from 100 grains and grain yields $\left(\mathrm{kg} \mathrm{ha}^{-1}\right)$.

All data were subjected to analysis of variance (ANOVA) using Statistix 8.0 version. Treatment means were compared where F-values were significant using Duncan's Multiple Range Test (DMRT) at 5\% level of probability (Duncan, 1955). Linear correlation coefficient (r) among the overall means of cowpea variety and physiological parameters were calculated at $5 \%$.

\section{Results and Discussion}

The soil was sandy loam and loam at Maiduguri and Damboa, respectively, and haved lower organic matter content at Maiduguri $(7.59 \mathrm{~g} / \mathrm{kg}$ ) than at Damboa $(13.54 \mathrm{~g} / \mathrm{kg})$. The $\mathrm{pH}$ of the soils was almost neutral at both sites while available phosphorus was higher at Maiduguri $(5.50 \mathrm{~g} / \mathrm{kg})$ than at Damboa $(1.80 \mathrm{~g} / \mathrm{kg})$ (Table 1). Based on the soil properties of the two sites it was ideal for cowpea growth.

Table 1: Physico-chemical characteristics of the soil at the experimental sites at Maiduguri and Damboa

\begin{tabular}{llll}
\hline S/No & Soil Characteristics & Maiduguri & Damboa \\
\hline & Chemical Analysis & & \\
1 & pH in $\mathrm{H}_{2} \mathrm{O}$ & 6.71 & 6.40 \\
2 & Organic carbon $(\mathrm{g} / \mathrm{kg})$ & 4.40 & 7.80 \\
3 & Organic matter $(\mathrm{g} / \mathrm{kg})$ & 7.59 & 13.45 \\
4 & Total N $(\mathrm{g} / \mathrm{kg})$ & 0.05 & 0.84 \\
5 & Available potassium $(\mathrm{me} / 100 \mathrm{~g})$ & 0.29 & 0.28 \\
6 & Available phosphorus $(\mathrm{g} / \mathrm{kg})$ & 5.30 & 1.80 \\
& Mechanical Analysis $(0-15 \mathrm{~cm}$ depth) & & \\
& Clay $(\%)$ & 15.0 & 26.1 \\
2 & Sand $(\%)$ & 70.0 & 44.8 \\
3 & Silt $(\%)$ & 15.0 & 29.1 \\
4 & Field Texture & Sandy loam & Loam \\
\hline
\end{tabular}

The effect of years show that the number of branches per plant was significantly higher in 2007 (3.45) than in 2006 (2.85) (Table 2). Similarly, number of branches per plant and grain yield was significantly higher at Damboa location (3.45) than at Maiduguri location (2.94) (Table 2). The results were in agreement with those of Jindal and Gupta (1984) who reported that numbers of branches per plant were found to be most important character in cowpea. Simlarly, Jakai (1995) reported that the highest contributors to seed yield appear to be branch number, pod number and seeds per pod. Average branch length per plant at physiological maturity did not differ among the locations or years, however, branch length per plant differed significantly among the cowpea varieties (Table 2). Among the varieties, Kannando White and Borno Brown local varieties significantly 
produced the longest branches and lowest yields compared to the rest of the varieties (Table 2). These findings were contrary to those of Erkskine and Khan (1975) who

Table 2: Effects of year, location and variety on morphological parameters of cowpea varieties at Maiduguri and Damboa in 2010 and 2011 combined

\begin{tabular}{|c|c|c|c|c|c|c|c|c|c|}
\hline Treatment & $\begin{array}{l}\text { Number } \\
\text { of } \\
\text { branches } \\
\text { per plant }\end{array}$ & $\begin{array}{l}\text { Branch } \\
\text { length } \\
(\mathrm{cm})\end{array}$ & $\begin{array}{l}\text { Number } \\
\text { of } \\
\text { peduncles } \\
\text { per plant }\end{array}$ & $\begin{array}{l}\text { Peduncle } \\
\text { length } \\
(\mathrm{cm})\end{array}$ & $\begin{array}{l}\text { Number } \\
\text { of pods } \\
\text { per } \\
\text { plant }\end{array}$ & $\begin{array}{l}\text { Number } \\
\text { of seeds } \\
\text { per pod }\end{array}$ & $\begin{array}{l}\text { Pod } \\
\text { length } \\
(\mathrm{cm})\end{array}$ & $\begin{array}{l}\begin{array}{l}\text { Number } \\
\text { of } \\
\text { matured }\end{array} \\
\text { seeds } \\
\text { from } \\
100 \\
\text { grains }\end{array}$ & $\begin{array}{l}\text { Grain } \\
\text { yield } \\
\left(\mathrm{kg} \mathrm{ha}^{2}\right)\end{array}$ \\
\hline \multicolumn{10}{|l|}{ Year } \\
\hline 2006 & $2.85^{\mathrm{b} 1}$ & 85.96 & 7.38 & $28.65^{\mathrm{b}}$ & $8.24^{\mathrm{b}}$ & $8.63^{\mathrm{a}}$ & 14.08 & $94.58^{\mathrm{b}}$ & 785.31 \\
\hline 2007 & $3.45^{\mathrm{a}}$ & 84.43 & 7.06 & $31.26^{\mathrm{a}}$ & $12.16^{\mathrm{a}}$ & $8.01^{\mathrm{b}}$ & 15.46 & $96.73^{\mathrm{a}}$ & 865.99 \\
\hline $\mathrm{SE}( \pm)$ & 0.077 & 3.725 & 0.352 & 0.642 & 0.507 & 0.208 & 0.771 & 0.363 & 30.635 \\
\hline \multicolumn{10}{|l|}{ Location } \\
\hline Maiduguri & $2.94^{\mathrm{b}}$ & 81.96 & $5.98^{\mathrm{b}}$ & 29.48 & $9.04^{\mathrm{b}}$ & $8.64^{\mathrm{a}}$ & 13.92 & 95.38 & $745.02^{\mathrm{b}}$ \\
\hline Damboa & $3.45^{\mathrm{a}}$ & 88.49 & $8.45^{\mathrm{a}}$ & 30.43 & $11.36^{\mathrm{a}}$ & $8.00^{\mathrm{b}}$ & 15.60 & 95.94 & $906.28^{\mathrm{a}}$ \\
\hline $\mathrm{SE}( \pm)$ & 0.077 & 3.725 & 0.352 & 0.642 & 0.507 & 0.208 & 0.771 & 0.363 & 30.635 \\
\hline \multicolumn{10}{|l|}{ Variety } \\
\hline IT90K-277-2 & $3.00^{\mathrm{b}}$ & $64.30^{\mathrm{cd} 1}$ & $9.12^{\mathrm{a}}$ & $35.05^{\mathrm{ab}}$ & $13.50^{\mathrm{a}}$ & 8.59 & 17.81 & 96.83 & $1034.9^{\mathrm{ab}}$ \\
\hline Kannanado White & $3.18^{\mathrm{b}}$ & $137.10^{\mathrm{a}}$ & $4.27^{\mathrm{e}}$ & $14.79^{\mathrm{d}}$ & $6.07^{\mathrm{d}}$ & 7.66 & 13.71 & 95.75 & $451.4^{\mathrm{d}}$ \\
\hline IT97K-499-35 & $2.47^{\mathrm{c}}$ & $42.76^{\mathrm{e}}$ & $8.06^{\mathrm{a}-\mathrm{c}}$ & $31.95^{\mathrm{b}}$ & $12.13^{\mathrm{ab}}$ & 8.68 & 13.87 & 96.41 & $1158.4^{\mathrm{a}}$ \\
\hline Borno Brown & $3.30^{\mathrm{ab}}$ & $144.49^{\mathrm{a}}$ & $5.14^{\mathrm{de}}$ & $19.11^{\mathrm{c}}$ & $6.85^{\mathrm{d}}$ & 7.36 & 13.83 & 94.92 & $484.0^{\mathrm{d}}$ \\
\hline $\begin{array}{l}\text { IT89KD-391 } \\
\text { IT97K-568-18 }\end{array}$ & $\begin{array}{l}3.05^{\mathrm{b}} \\
3.32^{\mathrm{ab}}\end{array}$ & $\begin{array}{l}48.74^{\text {de }} \\
71.44^{\mathrm{c}}\end{array}$ & $\begin{array}{l}8.87^{\mathrm{ab}} \\
6.96^{\mathrm{b}-\mathrm{d}}\end{array}$ & $\begin{array}{l}36.92^{\mathrm{a}} \\
33.86^{\mathrm{ab}}\end{array}$ & $\begin{array}{l}11.02^{\mathrm{a}-\mathrm{c}} \\
10.43^{\mathrm{bc}}\end{array}$ & $\begin{array}{l}8.87 \\
8.67\end{array}$ & $\begin{array}{l}14.66 \\
14.78\end{array}$ & $\begin{array}{l}95.67 \\
94.92\end{array}$ & $\begin{array}{l}864.0^{\mathrm{bc}} \\
844.6^{\mathrm{bc}}\end{array}$ \\
\hline IT98K-131-2 & $3.20^{\mathrm{b}}$ & $75.62^{\mathrm{c}}$ & $8.93^{\mathrm{ab}}$ & $36.47^{\mathrm{ab}}$ & $12.80^{\mathrm{ab}}$ & 8.36 & 15.04 & 94.83 & $1019.1^{\mathrm{ab}}$ \\
\hline IT89KD-288 & $3.67^{\mathrm{a}}$ & $97.32^{\mathrm{b}}$ & $6.41^{\mathrm{cd}}$ & $31.50^{\mathrm{b}}$ & $8.78^{\mathrm{cd}}$ & 8.47 & 14.37 & 95.92 & $748.8^{\mathrm{c}}$ \\
\hline $\mathrm{SE}(+)$ & 0.155 & 7.450 & 0.704 & 1.283 & 1.014 & 0.416 & 1.542 & 0.725 & 61.270 \\
\hline
\end{tabular}

$1=$ Means within a column and treatment followed by similar letter(s) are not significantly different $(\mathrm{P} \leq 0.05)$ according to Duncan's Multiple Range Test (DMRT).

reported that the ten highest yielding varieties had on average longer main stems and lateral branches. However it has been suggested that this type of growth habit is inefficient in grain yield production because of its low pod to stem ratio, its tendency to perenniality and its uneven pod ripening (Haizel, 1972; Ezedinma (1965).

The effect of year on the number of peduncles was not significant, while the locations and the varieties averaged across the locations and the years had significant effect on the number of peduncles per plant (Table 2). At Damboa there were significantly more peduncles produced per plant than in Maiduguri. Among the varieties, IT90K-277-2, IT97K-499-35, IT89KD-391 and IT98K-131-2 significantly produced the highest number of peduncles per plant than the other varieties (Table 2). This is an indication that grain yield is a function of different yield attributing characters. These could be the major grain determinants that contributed positively to the superior grain yield of these varieties evaluated in this trial. Mean peduncle length was statistically different between years (Table 2). In 2007 average peduncle length was significantly longer (31.26 $\mathrm{cm})$ than in $2006(28.65 \mathrm{~cm})$. Conversely, average peduncle length was similar between locations without significant differences (Table 2). Averaged across both locations and both years the varieties IT90K-277-2, IT89KD-391, IT97K-568-18 and IT98K-131-2 produced significantly the longest peduncles per plant compared with the rest of the other varieties (Table 2). Cowpea cultivars having canopies with pods displayed above the leaves (long peduncles) have advantages with respect to providing fewer oviposition sites for pod borer (Maruca testulalis, Geyer) (Hall et al., 1997). Under rain fed conditions, pods displayed above the canopy are also less likely to be damaged by various wet and dry pod rot organisms because they dry out more rapidly after the rain ends than pod retained inside the canopy. Moreover, pods displayed above the canopy are easier to harvest by hand than pods retained within the canopy. Consequently, there is some merit in having cultivars with pods displayed above the canopy for rain fed production in wetter areas of Africa, where the crop is manually harvested. $\quad$ Number of pods per plant was significantly higher in 2007 (12.16) than in 2006 (8.24) (Table 2). Similarly, number of pods per plant was significantly higher in Damboa (11.36) than in Maiduguri (9.04) (Table 2). Averaged across both locations and both years number of pods per plant was significantly higher in IT90K-277-2, IT97K-499-35, IT89KD-391 and IT98K-131-2 compared with the rest of the varieties (Table 2). 
Number of seeds per pod was statistically higher in 2006 (8.63) than in 2007 (8.01). Also number of seeds per pod was significantly greater in Maiduguri (8.64) than in Damboa (8.00) (Table 2). Averaged across both locations and both years mean number of seeds per pod was statistically similar among all the varieties evaluated (Table 2). Pod length at physiological maturity did not differ among locations or years and similarly, pod length was similar among varieties tested when averaged across both locations and both years (Table 2). A similar report was made by Muli and Saha (2008) who reported that pod length for different cultivars was 13 to $20 \mathrm{~cm}$. The range for this study is also within that which was documented as characteristic for the cowpea crop (Kay, 1979). In terms of pod length, the cultivars did not exhibit much difference between the two sites. This shows that environment have very little influence over the parameter.

Mean number of matured seeds from 100 grains was statistically different between years (Table 2). In 2007 average number of matured seeds from 100 grains was significantly higher (96.73) than in 2006 (94.58). In contrast, average number of matured seeds from 100 grains was similar between locations without significant differences (Table 2). Number of matured seeds from 100 grains did not differ significantly among varieties averaged across both years and locations (Table 2). The effects of year, location and variety on cowpea grain yield at Damboa and Maiduguri in 2006 and 2007 (overall mean) is presented in Table 2. The effect of year on the grain yield $\left(\mathrm{kg} \mathrm{ha}^{-1}\right)$ was not significant, while the locations and the varieties across the locations and years had significant effect on cowpea grain yield per hectare (Table 2). At Damboa there were significantly higher grain yields $\left(906.28 \mathrm{~kg} \mathrm{ha}^{-1}\right)$ than in Maiduguri $\left(745.02 \mathrm{~kg} \mathrm{ha}^{-1}\right)$. This may be because of edaphic factors such as soil properties and fertility could also influence the yield potential of an environment (Akande, 2007). The result of this trial is in agreement with that of Nielsen and Hall (1985) who reported that grain yield of cowpea varies widely when grown at different locations. Among the varieties, IT90K-277-2, IT97K-499-35 and IT98K-131-2 significantly produced the highest grain yields $\left(\mathrm{kg} \mathrm{ha}^{-1}\right)$ than the other varieties (Table 2$)$. The local varieties produced significantly the lowest grain yields $\left(\mathrm{kg} \mathrm{ha}^{-1}\right)$ (Table 2). Despite the high yield potentials of the three varieties mentioned above, their adoption by farmers may be of some concern. For Kamara et al. (2010) reported that despite the yield benefits of new varieties farmers have shown preference for local ones, even when introduced varieties give higher grain yields. The reasons among others are ability for relay planting with creeping habit and ability to smother weeds.

\section{Interrelationships among Morphological Parameters}

The correlation coefficients (r) for all possible comparisons between morphological traits and grain yield averaged over both locations and both years (overall mean) are presented in Table 3 . The results showed that cowpea grain yield was significantly positively correlated with number of pods per plant, peduncle length and number of peduncles per plant (Table 3). Conversely, the results indicated that cowpea grain yield was significantly negatively correlated with branch length (Table 3). Peduncle length had a highly significant positive correlation with number of peduncles per plant (Table 3). Number of pods per plant had a significant positive correlation with peduncle length and number of peduncles per plant (Table 3). Contrary with the results of this study, Nakawuka and Adipala (1999) reported that there was highly significant positive correlation between number of seeds per pod and pod length.

Table 3: Correlation coefficients among grain yield and morphological parameters tested combined in 2010 and 2011 at Maiduguri and Damboa

\begin{tabular}{llllllllll}
\hline & GY & BL & BPP & PDL & PDPP & PL & PPP & MSHG & SPP \\
\hline GY & 1.00 & & & & & & & & \\
BL & $-0.48^{* *}$ & 1.00 & & & & & & & \\
BPP & -0.05 & $0.25^{* *}$ & 1.00 & & & & & & \\
PDL & 0.12 & 0.01 & 0.09 & 1.00 & & & & & \\
PDPP & $0.60^{* *}$ & $-0.30^{* *}$ & 0.16 & 0.14 & 1.00 & & & & \\
PL & $0.56^{* *}$ & $-0.63^{* *}$ & -0.01 & 0.13 & $0.52^{* *}$ & 1.00 & & & \\
PPP & $0.53^{* *}$ & $-0.31^{* *}$ & 0.05 & 0.05 & $0.62^{* *}$ & $0.46^{* *}$ & 1.00 & & 1.00 \\
MSHG & 0.18 & -0.03 & 0.08 & 0.15 & $0.22^{*}$ & 0.05 & 0.05 & 1.00 & -0.14 \\
SPP & 0.05 & -0.14 & $-0.25^{\mathrm{b}}$ & 0.07 & -0.15 & 0.11 & -06 & \\
\hline
\end{tabular}


$\mathrm{GY}=$ Grain yield, $\mathrm{BPP}=$ Branches per plant, $\mathrm{BL}=$ Branch length, $\mathrm{PPP}=$ Peduncles per plant, $\mathrm{PL}=\mathrm{Peduncle}$ length, $\mathrm{MSHG}=$ Matured seeds from 100 grains, $\mathrm{PDPP}=\mathrm{Pods}$ per plant, $\mathrm{PDL}=\mathrm{Pod}$ length, $\mathrm{SPP}=\mathrm{Seeds}$ per pod, $* *=$ Highly significant at $1 \%$ probability level, $*=$ Significant at $5 \%$ probability level.

\section{Conclusions}

In this study, the improved varieties performed better than the local varieties in the Sudan Savanna zone of Borno State. For the improved varieties had significantly higher grain yield per hectare. Among the improved varieties, IT90K-2772, IT97K-499-35 and IT98K-131-2 were outstanding in terms of yield. There is the need for breeding work between the improved and the local varieties to harmonize their outstanding advantages over the other. Though the local varieties had significantly the lowest grain yield they also had significantly the longer branches. Therefore there is the need for breeding work on these parameters to increase cowpea yield.

\section{Recommendations}

From the findings of this study the improved varieties of cowpea were found suitable in the Sudan savanna zone of Nigeria and could be recommended for adaptive farm trials. Among the varieties, IT90K-277-2, IT97K-499-35 and IT98K131-2 should be tried for further performance evaluation under farmer's environment for high yield, longer and more number of branches.

\section{References}

[1]. Akande, S. R. (2007). Biplot analysis of genotype by environment interaction of cowpea grain yield in forest and southern guinea savanna agro-ecologies of Nigeria. Journal of Food, Agriculture and Environment 5:(3\&4),464-467.

[2]. Anonymous (2008). Cowpea: Abuja Securities and Commodity Exchange PLC. http://www.abujacomx.com

[3]. Duncan, O.B. (1955). Multiple Range and Multiple F-tests. Biometrics 11: 1-42.

[4]. Erkskine, W. and Khan, T. N. (1975). Evaluation of cowpea germplasm for grain yield potential in Papua New Guinea.Sabrao Journal 7 (2): 189-196.

[5]. Ezedinma, F. O. C. (1965). Some studies on the vegetative and reproductive patterns in cowpeas (Vigna unguiculata (L.) Walp) in Southern Nigeria. Niger. Agric. J. 2:32-4.

[6]. FAO, (2000). Site internet : http / www . FAO.org./statistics.

[7]. Gibbon, D. and Pain, A. (1988). Crops of the drier regions of the tropics. ELBS / Longman. $157 \mathrm{pp.}$

[8]. Haizel, K. A. (1972). The effects of plant density on the growth, development and grain yield of two varieties of cowpea, Vigna unguiculata (1.) Walp. Ghana J. Agric. Sci. 5: 163-171.

[9]. Hall, A. E., Singh, B. B. and Ehlers, J. D. (1997). Cowpea Breeding. Plant Breeding Review 15: $215-274$.

[10]. Jackai, L. E. N. (1985). The legume pod borer Maruca vitrata, and its principal host plant Vigna unguiculata (L.) Walp. Use of selective insecticide sprays as an aid in the identificatioin of useful levels of resistance. Crop Protection 14: 299-306.

[11]. Jindal, S. K.and Gupta, B. S. (1984). Component analysis of yield in cowpea. J. Agric. Sc. 54 (3): 183-5.

[12]. Kamara, A. Y., Ellis-Jones, J., Ekeleme, F., Omoigui, L. O. Amaza, P. S. Chikoye, D., and Dugje, I. Y. (2010). A participatory evaluation of improved cowpea cultivars in the Guinea and Sudan savanna zones of north east Nigeria. Achives of Agronomy and Soil Science. 56 (3): 355-370.

[13]. Kay, D. E. (1979). Food legumes. Tropical Development and Research Institute. London.

[14]. Muleba, N. C., Dabire, J. B. S., Drabo, I. and Ouedraogo, J. T. (1997). Technologies for cowpea production based on genetic and environmental manipulations in the semi-arid tropics. Pages 192-206 in Technologies options for sustainable agriculture in subSaharan Africa, edited by Bezuneh, T.; Emechebe, A. M.; Sedgo, J. and Oeudrago, M. Publication of the Semi-Arid Food Grain Research and Development Agency (SAFGRAD) of the Scientific, Technical and Research Commission of OAU Ouagadougou, Burkino Faso.

[15]. Muli, M. B. and Saha, H. M. (2008). Participatory evaluation of cowpea cultivars for adaptation and yield performance in coastal Kenya. Kenya Agricultural Research Institute, Regional Research Centre, Mtwapa P.O Box 16, Kikambala.

[16]. Nakawuka, C. K. and Adipala, E. (1999). A path coefficient analysis of some yield components interactions in cowpea. African Crop Science Journal 7: 4, 327-331.

[17]. Nielsen, S. S., Ohler, T. A. and Mitchell, C. A. (1997). Cowpea leaves for human consumption, utilization, and nutrient composition. Pages 326-332 in Advances in cowpea research, edited by Singh, B. B., Mohan Raj, D. R., Dashiel, K. E. and Jackai, L. E. N. Copublication of International Institute of Tropical Agriculture (IITA) and Japan International Research Centre for Agricultural Sciences (JIRCAS). IITA,Ibadan, Nigeria.

[18]. Onyibe, J. E., Kamara, A. Y. and Omoigui, L. O. (2006). Guide to cowpea production in Borno State, Nigeria. Promoting Sustainable Agriculture in Borno State (PROSAB). Ibadan, Nigeria. 36pp.

[19]. Raheja, A. K. (1986). Problems and prospects of cowpea production in the Nigerian Savannas. Pages.13-15 in Tropical grain legume bulletin. World Cowpea Research Confernce, 5-7 November 1986, 32, IITA, Special Issue.

[20]. Singh, B. B. (1994). Breeding suitable cowpea varieties for West and Central African Savanna. Pages 77-85 in Progress in food grains research and production in Semi-Africa, edited by Menyonga, J. M., Bezuneh, J. B., Yayock, J. Y. and Soumana, I. OAU / STRC-SAFGRAD, Ouagadougou, Burkino Faso.

[21]. Singh, B. B. (2007). Potential and constraints of improved cowpea varieties in increasing the productivity of cowpea-cereal systems in the dry Savannas of West Africa. Pages 14-26 in Majiwa, P., Odera, M., Muchiri, N., Omanya, G. and Werehire, P. (eds). A plan to apply technology in the improvement of cowpea productivity and utilisation for the benefit of farmers and consumers in Africa: Proceedings of cowpea stakeholders workshop. Nairobi Kenya: African Agricultural Technology Foundation.

[22]. Singh, S. R., Jackai, L. E. N., Dos Santos, J. H. R. and Adalla, C.B. (1990). Insect pests of cowpea. Pages 43-89 in Insect pests of tropical food legumes, edited by Singh, S.R. John Wiley and Sons Ltd, Chichester, England.

[23]. Tarawali, S. A., Singh, B. B., Peters, M. and Blade, S. F. (1997). Cowpea haulms as fodder. Pages 313-325 in Advances in cowpea research, edited by Singh, B. B., Mohan Raj, D. R., Dashiel, K. E. and Jackai, L. E. N. Copublication of International Institute of Tropical Agriculture (IITA) and Japan International Research Centre for Agricultural Sciences (JIRCAS). IITA,Ibadan,Nigeria. 